\title{
多様な燃料組成に対応可能な小型ガスエンジンシステムの開発*
}

\author{
山崎由大*1, 西澤 幸 紘*1, 金子成 彦*2
}

\section{Development of Fuel Flexible Gas Engine System}

\author{
Yudai YAMASAKI*3, Yukihiro NISHIZAWA and Shigehiko KANEKO \\ ${ }^{* 3}$ Department of Mechanical Engineering, The University of Tokyo, \\ 7-3-1 Hongo, Bunkyo-ku, Tokyo, 113-8656 Japan
}

\begin{abstract}
In this study, the authors aim to develop a small gas engine system for biomass gas by modifying the control system of a conventional spark ignition engine. Before developing a control algorithm, combustion experiments with various components fuels assuming component of real biomass gases like as fermentation gas and pyrolysis gas were carried out. It was clarified that the relationship between dimensionless combustion duration and equivalence ratio is expressed in first order liner function regardless of fuel components. Indicated thermal efficiency can be also expressed by combustion duration and volumetric efficiency under the condition that COV of IMEP was lower than $5 \%$ and pumping loss decreased against volumetric efficiency linearly, and the relationship between combustion duration and MBT can also be expressed in first order function. By using these relationships, a gas engine control algorithm, which can define target values of equivalence ratio of premixture and ignition timing realizing high thermal efficiency for fuel compositions automatically analyzing in-cylinder gas pressure data in real time, is developed in order to use gaseous fuels produced from biomass resources effectively. Thus, biomass fueled gas engine system is developed by applying the algorithm to the automobile gasoline engine, hardware modification of which were only fuel supply system and flywheel. The engine system was connected to a gasification plant using wood chip and operation test was carried out: As a result, the engine system could set optimum premixture condition and ignition timing, which realized stable and high thermal efficiency operation automatically.
\end{abstract}

Key Words : Internal Combustion Engine, Gaseous Fuel, Biomass Energy, Controller

\section{1.はじめに}

石油資源の先行き不透明さ，地球温暖化等の環境問 題の観点から, 新エネルギーの有效利用が急務であり, また今後内燃機関に用いられる燃料は多様になると考 えられる．新エネルギーの一つであるバイオマス資源 に着目すると，各地に散在しており，特に国内におい てはその収集に掛かるエネルギー，コストが大きくな る. そのため，大規模な発電設備よりも，小規模な， いわゆる地産地消での利用が理想的と考えられる.

バイオマスをガス化した場合, 資源の種類やガス化 方法により燃料の平均組成は異なり，またガス化条件 によっても組成の時間変動が生じる ${ }^{(1)}$. さらに, ガ ス化したバイオマス（以下バイオマスガス）は不燃成 分を多く含み，都市ガス等に比べて発熱量が低いとい う特徵がある. バイオマスガスをレシプロエンジンに 用いる場合には，燃料組成の変化がエンジン内燃焼に 影響し，エンジン性能が変化することに対処する必要 がある.ここで，バイオマス資源の違いなどによる燃 料の平均的な組成の変化については，事前の成分分析

* 原稿受付 2009 年 7 月 17 日.

*1 正員, 東京大学大学院工学系研究科( (113-8656 東京都文 京区本郷 7-3-1).

*2 正員, フェロー, 東京大学大学院工学研究科.

E-mail : yudai_y@fiv.t.u-tokyo.ac.jp
により，エンジン制御系の諸パラメータを運転前に変 更すれば対応も可能となるが，ガス化条件の変化によ る組成の時間変化が大きな場合は, エンジンの安定し た運転が困難となる場合がある. 大型エンジンでは, 自身が成分変動を吸収するバッファーとなり，さらに 燃焼室一の助燃用の軽油パイロット噴射や予燃焼室力 式などの採用 ${ }^{(2)}$ により，確実な着火，燃焼を実現し ている. しかし，ハードウェア変更はコストの増加に つながり，小規模な分散型発電システムで用いられる 数十 $\mathrm{kW}$ 程度の小型エンジンでは，そのような補助装 置の設置はスペース的にも困難で実用には至っていな い.このように，バイオマスガスを小型エンジンで用 いる場合は, 様々な燃料組成やその時間変動に対応し, さらに要求出力も時間変化する場合においても, その 変動を吸収し, 安定した高効率な運転が要求される.

著者らはこれまでに，低カロリーで，組成が様々な 然料でも安定した発電を行える小型のガスエンジン の開発研究を行ってきた. 低カロリーな然料でも，そ の組成に応じて，予混合気条件を整えれば安定した着 火，燃焼が可能であることを明らかにした ${ }^{(3)}$ 。ま た，エンジン運転中に，燃焼圧をリアルタイムに熱力 学的な解析を行うことで，燃料の低位発熱量を瞬時に 
Tablel Engine specification

\begin{tabular}{|l|l|}
\hline Type name & TOYOTA 2GR-FE \\
\hline Type & V-type, 6cylinders \\
\hline Displacement cc & 3456 \\
\hline Bore and stroke mm & $94 \times 83$ \\
\hline Compression ratio & 10.8 \\
\hline
\end{tabular}

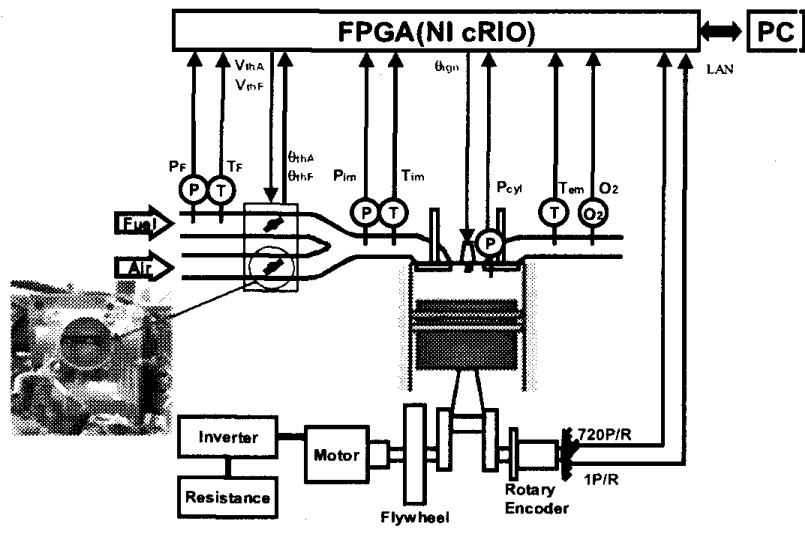

Fig. 1 Engine system

推定し，そこから理論空然比を導き出し，目標とする 当量比に制御するアルゴリズムを開発し，組成が変化 しても安定した運転を実現することに成功した ${ }^{(4)}$.

本研究では，これまでに構築したアルゴリズム ${ }^{(4)}$ を応用し，燃料組成がエンジン運転中に変化する条件 を想定し，その燃料に対して高効率運転を実現できる 予混合気条件, 点火時期をリアルタイムに判断する自 動運転制御アルゴリズムの構築を行った. さらに，そ の制御アルゴリズムを自動車用ガソリンエンジンを改 造したシステムに実装し，実際のガス化炉に接続して 運転試験を行った結果を報告する。

\section{2. 実験装置および実験方法}

2 -1 エンジンシステム本研究では, 自動車用 ガソリンエンジンを転用して使用した。 エンジン諸元 を表 1 に，システム概要を図 1 に示す.エンジンの主 な改造点は，然料供給系とフライホイルである. 燃料 供給系については，エンジンをバイオマスのガス化炉 に接続して運転することを前提に，ガス化炉から供給 される生成ガスの圧力がほぼ大気圧であることを考慮 して，空気と同じくスロットルバルブにより流量を制 御することとした. なお，システム構築時に想定した バイオマスガス $\left(\mathrm{H}_{2}: \mathrm{CO}: \mathrm{CH}_{4}: \mathrm{N}_{2}: \mathrm{CO}_{2}=30: 17: 3: 30: 20\right.$,

$\mathrm{LHV}=6.5 \mathrm{MJ} / \mathrm{Nm}^{3}$ ) の理論空燃比は 1.48 であり, 空気と 燃料の流量差が小さくなることから, 燃料, 空気共に バタフライ直径 $\phi=42 \mathrm{~mm}$ の電子スロットルを使用した. また，発電用途のため，回転数の変動は小さいことが 望ましく, 慣性モ一メントの大きな $\left(330 \times 10^{3} \mathrm{~kg}(\mathrm{~mm})^{2}\right)$ フライホイルを製作し使用した。燃料流量および空気 流量を計測するために，燃料用スロットル上流，空気
および然料スロットル後の配管集合部の 2 箇所に絶対 圧センサーを設置した．その他，ロータリーエンコー ダーをクランク軸に設置し，運䡛制御およひ燃焼解析 の基準信号として用い，燃焼室の 1 つに筒内圧力セン サー (Kistler 6125B) を取り付け燃焼状態をモニターし た. クランク軸に取り付けたインバーターモーターに より，起動および発電を行った. エンジンコントロー ラーは汎用の FPGA を用いて構築した。 なお, 予混合 気条件を決定するアルゴリズムの構築においては，3 気筒エンジン (ボアメストローク $: 88 \times 90$, 圧縮比 9.8) での実験データを用いた。

$2 \cdot 2$ バイオマスガス供給系 燃料のバイオマス ガスは，高圧ボンベを使った模擬バイオマスまたはガ ス化炉からの実バイオマスを使用した. 模擬バイオマ スガスは， $\mathrm{H}_{2}, \mathrm{CO}, \mathrm{CH}_{4}, \mathrm{~N}_{2}, \mathrm{CO}_{2}$ の高圧ボンベを用 意し，マスフローコントローラーにより各成分を任意 に調整しバイオマスガスの組成を模擬してエンジン へ供給した．実証試験では，木質系のバイオマスをロ ータリーキルンとダウンドラフト炉を組み合わせた ガス化炉 (5) に供給し，その生成ガスを用いた.

\section{3. エンジン制御アルゴリズムの構築}

燃料組成が変化しても安定して高効率な運転を行 うために, 制御項目は当量比, 点火時期とし, また発 電用途のために一定回転数での運転を行うエンジン の自動制御アルゴリズムを構築した. 構築した制御シ ステムのブロック線図を図 2 に示す. 制御部は回転数 制御部，当量比制御部，点火時期制御部から構築され ており，アクチェエーターは空気用スロットル, 燃料 用スロットル，スパークプラグであり，いずれもフィ ードバック制御を行い，コントローラーには PID を用 いた. インテークマニホールド圧力, 燃料マニホール ド圧力, エンジン回転数, 燃料用スロットル位置, 空 気用スロットル位置, 筒内ガス圧力を, まず然焼解析 ブロックに入力し, 理論空燃比, 体積効率, 当量比, 燃焼期間および図示出力を得る. 次に, 高効率運転条 件予測ブロックで, 燃料の燃焼特性に応じて高効率に 運転できる当量比および点火時期を導出する. 以下に, 燃焼解析ブロックで行う計算過程および高効率運転 条件予測ブロックで行う計算過程を示す。

$3 \cdot 1$ 燃焼解析ブロック このブロックにおい ては主に，空気流量およひ燃料流量の推定，熱発生に 関する計算，低位発熱量，理論空然比，当量比の推定 を行い，燃焼状態の把握を行う。

3-1・1 空気流量およひ燃料流量の推定 空気 の質量流量, 燃料の質量流量は空気用スロットル, 燃 


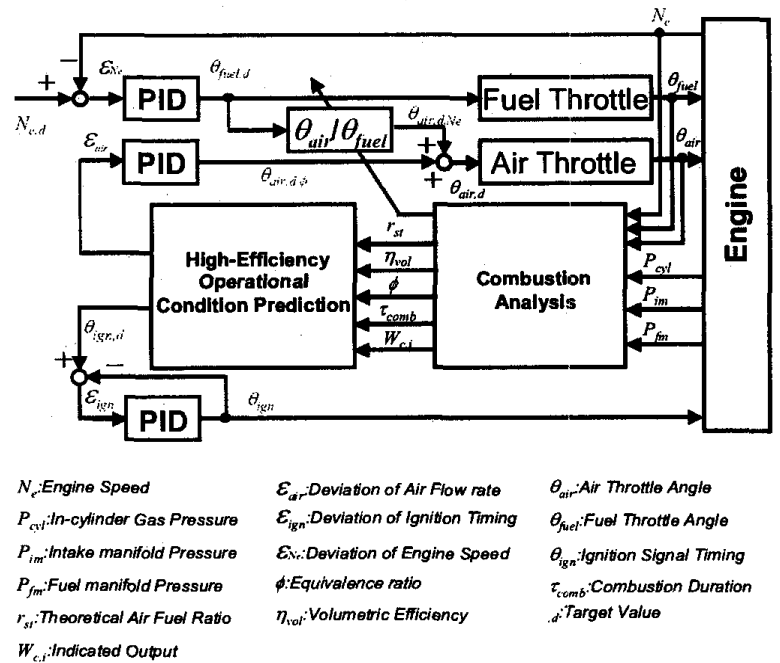

Fig.2 Block diagram of a developed engine controller

料用スロットルそれぞれのスロットル開度と，その上 流側と下流側の土力および温度から求めた. なお, 空 気用スロットルの上流側圧力は大気圧とした。

3・1-2 熱発生に関する計算１サイクル毎に 熱発生率 (式（1））を求め, さらにその熱発生率を 積算した燃焼熱（式（2））を求める。また熱発生率 の幾何学的形状を二等辺三角形と仮定し, 先に求めた 燃焼熱がその二等辺三角形の面積相当とし，燃焼熱を 熱発生率ピーク值で除した值の 2 倍の值 (式 (3)) を燃焼期間と定義した．また 1 サイクルの図示仕事 $W_{c, i}$ (式 (4)) も求めた.

$$
\begin{aligned}
& \frac{d Q_{c o m b}}{d \theta_{C A}}=\frac{1}{\kappa-1}\left(\kappa P_{c y l} d V_{c y l}+V_{c y l} d P_{c y l}\right)
\end{aligned}
$$

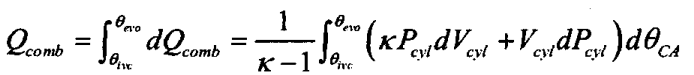

$$
\begin{aligned}
& \tau_{\text {comb }}=2 Q_{\text {comb }}\left(\frac{d Q_{\text {comb }}}{d \theta_{c A}}\right)_{\text {peak }} \text {. } \\
& W_{c, i}=\oint P_{c y l} d V_{c y l}
\end{aligned}
$$

$Q_{c o m b}[J]$ : 燃焼熱, $\theta_{C A}[\mathrm{deg}]$ : クランク角度, $k[-]$ : 比熱比 $(=1.4), P_{c y l}[\mathrm{~Pa}]$ :筒内圧力, $V_{c y l}\left[m^{3}\right]$ : 筒内体 積, $\tau_{\text {comb }}[\mathrm{deg}]$ : 燃焼期間, $W_{c, i}[J / c y c l e]$ : 図示仕事

\subsection{3 低位発熟量, 理論空燃比, 当量比の推定}

式（2）で求めた燃焼熱を用いると, 低位発熱量は式

（5）のように与えられる. ここで, バイオマスから 得られるガス燃料の代表的な可燃成分である $\mathrm{H}_{2}, \mathrm{CH}_{4}$, $\mathrm{CO}$ ，また，それらを任意の割合で含みさらに $\mathrm{N}_{2}$ や $\mathrm{CO}_{2}$ で任意の割合で希釈された燃料ガスについては, 圧力 および温度一定時において，単位体積当たりの低位発 熱量と, 理論混合時の燃料と空気の体積比の関係はほ ぼ線形となり，その関係は式（6）のように表すこと
ができる ${ }^{(4)}$ 。したがって，筒内ガス圧力を計測する ことで, 燃料の組成が末知の場合でも式 (1)，(2)，

（5），（6）よりリアルタイムに理論空然比を求め ることができる. また，先に求めた空気流量および然 料流量と式（7）より，エンジン運転時の当量比をリ アルタイムに求めることができる.ただし, 燃焼効率, 冷却効率は一般的な值とされる一定值 ${ }^{(6)}$ を使用した. また，燃料密度については，現在のところ一定値を 使っており，值はガス化炬に接続する場合は，ガス化 炬から供給されるガスをガスクロマトグラフ法によ って解析し得られたガス組成の平均密度をエンジン 運転前にプログラムに入力するものとする

$$
\begin{aligned}
& Q_{L H V}=\frac{293 \cdot 22.4}{273 \cdot m_{\text {futel }} / \rho_{\text {futel }}} \frac{n_{c v} \cdot N_{e}}{120} \frac{Q_{c o m b}}{\eta_{\text {comb }}\left(1-\phi_{w}\right)} \times 10^{-3} \\
& r_{s t}=-0.42+0.0124 Q_{L H V} \\
& \phi=\frac{r_{s t}}{m_{\text {air }} / m_{\text {futel }}}
\end{aligned}
$$

$Q_{L H V}[J]$ : 低位発熱量, $N_{e}[r p m]$ : エンジン回転数, $n_{c l 1}$ : シリンダ数, $\eta_{\text {comb }}[-]$ : 燃焼効率 $(=0.965), \quad \phi_{w}[-]$ : 冷却損失 $(=0.35), \phi[-]$ : 当量比, $r_{s t}$ : 理論空然比, $m_{\text {air }}[\mathrm{kg} / \mathrm{s}]$ : 空気流量, $m_{\text {fuel }}[\mathrm{kg} / \mathrm{s}]$ : 燃料流量, $\rho_{\text {fuel }}[\mathrm{kg} / \mathrm{Nl}]$ :燃料密度 (一定)

3・2 高效率運転条件予測ブロック 解析した 燃焼特性から，効率の良い制御目標值を自動的に設定 する万法について示す. 燃料の燃焼特性および当量比, 点火時期，運転条件によって，燃焼開始時期，燃焼期 間, ポンプ損失は異なる.ここで, 制御量は当量比, 点火時期，エンジン回転数であるが，発電用途での一 定回転数での運転を想定しているため，この内，高効 率運転をする上での制御量は当量比と点火時期とな る. 以下に，燃料および運転条件が時々刻々と変化す る条件で，効率の良い運転が可能となる当量比および 点火時期の目標值を自動的に決定する手順を示す．

\subsection{1 当量此の目椟值決定方法 燃焼期間が} 長期化しても，ポンピングロスを低减した希薄側での 運転か，ある程度のポンピングロスは不可避とし，量 論混合比付近で等容度を上げた運転のいずれが有効 かは燃料の燃焼特性により異なる. そこで当量比の目 標值を燃焼特性に応じてリアルタイムに設定する方 法を検討した. 当量比の変化により燃焼期間, 体積効 率，図示熱効率は変化するが，まず，これらの関係を 事前に行った定常実験でのデータをもとに整理した.

図 3 に体積効率と図示熱効率の関係を燃焼期間ご とに示す。なお，この時使用した燃料の組成は， $\mathrm{CH}_{4}$ が 9 100\%, $\mathrm{H}_{2}$ が 0 30\%, $\mathrm{CO}_{2}$ が 10〜 50\%, $\mathrm{N}_{2}$ が 10 


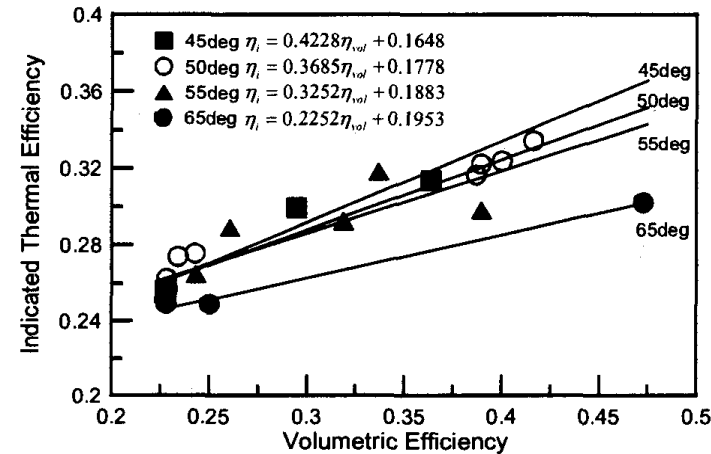

Fig.3 Relationship between volumetric efficiency and indicated thermal efficiency

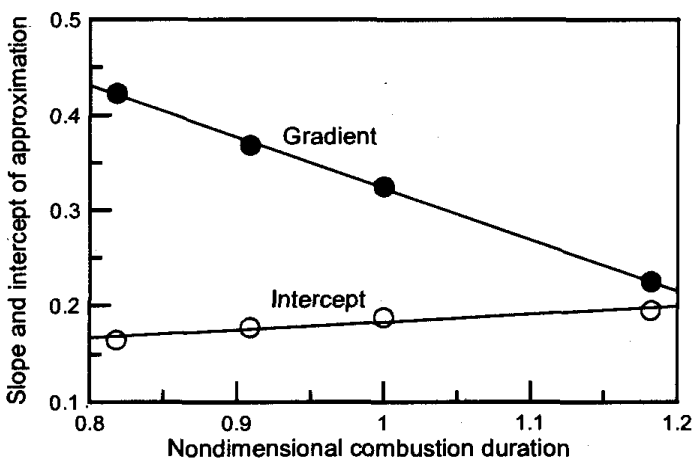

Fig. 4 Gradient and intercept of approximate liner function on volumetric efficiency and indicated thermal efficiency

〜60\%で，点火時期は-50〜-30degATDC，当量比は 0.8 〜1.0 の条件である. また，この燃料組成は，実際に バイオマスから生成されるメタン発酵系のガス $\left(\mathrm{CH}_{4}: \mathrm{CO}_{2}=60: 40\right.$ 程度) や熱分解ガス $\left(\mathrm{CH}_{4}: \mathrm{H}_{2}\right.$ : $\mathrm{CO}: \mathrm{N}_{2}$ and $\mathrm{CO}_{2}=0 \sim 15: 10 \sim 40: 10 \sim 30: 45 \sim 70$ 程 度)の組成に準じたものである. 燃焼期間 45deg, 50deg, 55deg，65deg の表示は，それぞれ燃焼期間が 45士2, $50 \pm 2,55 \pm 2,65 \pm 2 \mathrm{deg}$ の結果を示すものとする. 体 積効率が増加すると図示熱効率が向上しており，この 時ポンプ損失は体積効率に線形的に低下したことが 確認された，また，体積効率が同じ場合には，燃焼期 間の短期化により図示熱効率が向上したことが確認 できる.ここで，図に示すように，燃料によらず，燃 焼期間に対して図示熱効率と体積効率の関係を 1 次近 似できることが分かった.これはポンピングロスが， 体積効率の上昇に伴い，線形的に减少したことに起因 するものと考えられる. なお，発電用エンジンとして 許容される IMEP のサイクル変動值 (COV) は 5\%以 下とされており，一般的に燃焼期間が長くなると IMEP の COV は大きくなる. 使用したエンジンでは, $1500 \mathrm{rpm}$ から $1800 \mathrm{rpm}$ 程度の回転数では, IMEP の COV が 5\%以下となるような条件では燃焼期間は 65deg 程度までであった. そこで, IMEP の COV が 5\%

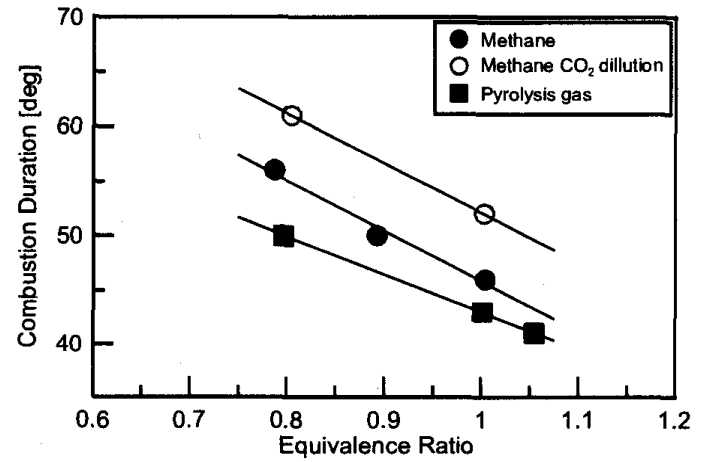

Fig. 5 Relationship between equivalence ratio and combustion duration

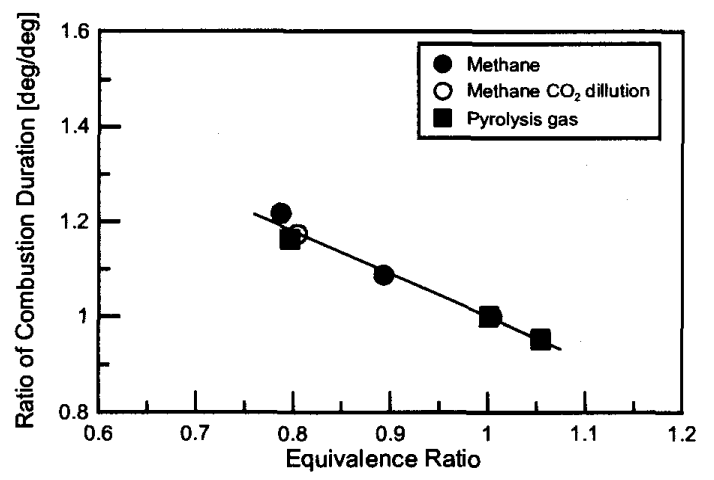

Fig.6 Relationship between equivalence ratio and non-dimensional combustion duration

以下となることを必要条件として，燃焼期間が 65deg よりも短くなる条件でのデータを用いた.

さらにこの近似直線の傾きと切片を燃焼期間の関 数と仮定すると, 近似直線の傾きと切片は, 燃焼期間 に対し図 4 に示すように 1 次線形となった. なお, 横 軸沲焼期間 55deg を代表燃焼期間として無次元化し た燃焼期間とした. 無次元燃焼期間が増加すると体積 効率と図示熱効率の 1 次近似直線の傾きは減少, 切片 は増加することが分かった，よって，燃焼期間および 体積効率 $\eta_{v o l}$ と図示熱効率 $\eta_{i}$ の関係を整理し, 式 (8) を得た。

$$
\eta_{i}=\left(-0.538 \frac{\tau_{\text {comb }}}{\tau_{c o m b, N}}+0.862\right) \eta_{v o l}+0.0814 \frac{\tau_{\text {comb }}}{\tau_{c o m b . N}}+0.102
$$

次に, 当量比と燃焼期間の関係を整理した (図 5). いずれの然料でも，負荷がおよそ士0.6kW一定の範囲 内で当量比が低下すると，燃焼期間は一次線形で長期 化した. ここで, 各燃料について, 当量比 1.0 時の燃 焼期間に対する燃焼期間の変化割合を縦軸にとり直 すと図 6 に示すようになり，然焼期間の無次元值は燃 料によらず当量比に対して 1 次線形となることが分 かった.よって，当量比が $\phi か ら \phi_{d} に$ 変化した場合の 燃焼期間の変化を次式によって近似した。

$$
\frac{\tau_{\text {comb }}\left(\phi_{d}\right)}{\tau_{\text {comb }}(\phi)}=\frac{-0.9 \phi_{d}+1.9}{-0.9 \phi+1.9}
$$


次に, 当量比と体積効率の関係について整理する. 一般的に体積効率と燃焼室にトラップされる予混合 気の質量は，式（10）で表すことができる.

$$
m_{\text {pre }}=\eta_{v o l} \times \frac{N_{e}}{120} \times V_{d} \times \frac{M_{p r e}}{22.4}
$$

なお, $M_{p r e}[\mathrm{~kg} / \mathrm{mol}]$ は予混合気の分子量

ここで, 当量比が変化する場合, 空気流量のみが変 化すると仮定すると, 式（１１）が成り立つ.

$\eta_{v o t}\left(\phi_{d}\right)-\eta_{10 t}(\phi)=\frac{120 \times 22.4}{N_{e} V_{D} M_{p r e}}\left(m_{\text {air }}\left(\phi_{d}\right)-m_{\text {air }}(\phi)\right)$

式（1 1) に式（7）の関係を代入すると，式（1 2) となり, 式 (13) が導出される.

$$
\begin{aligned}
& \eta_{v o l}\left(\phi_{d}\right)-\eta_{1 v l}(\phi)=\frac{120 \times 22.4}{N_{e} V_{D} M_{p r e}} r_{s t} m_{\text {futel }}\left(\frac{1}{\phi_{d}}-\frac{1}{\phi}\right) \\
&=\frac{120 \times 22.4}{N_{e} V_{D} M_{p r e}} m_{p r e} \frac{r_{s t} \phi}{r_{s t}+\phi}\left(\frac{1}{\phi_{d}}-\frac{1}{\phi}\right) \\
&=\eta_{v o l}(\phi) \frac{r_{s t} \phi}{r_{s t}+\phi}\left(\frac{1}{\phi_{d}}-\frac{1}{\phi}\right) \\
& \eta_{v o l}\left(\phi_{d}\right)=\eta_{v o l}(\phi)\left(1+\frac{r_{s t} \phi}{r_{s t}+\phi}\left(\frac{1}{\phi_{d}}-\frac{1}{\phi}\right)\right)
\end{aligned}
$$

式（8），（9），（1 3）より図示熱効率は，当 量比と燃焼期間の関数として式（14）が得られた。

$$
\begin{aligned}
\eta_{i}= & \left(-0.54 \frac{\tau_{c o m b}(\phi)}{\tau_{c o m b, N}} \frac{-0.9 \phi_{d}+1.9}{-0.9 \phi+1.9}+0.86\right) \\
& \times \eta_{v o l}(\phi)\left(1+\frac{r_{s t} \phi}{r_{s t}+\phi}\left(\frac{1}{\phi_{d}}-\frac{1}{\phi}\right)\right) \\
& +0.081 \frac{\tau_{c o m b}(\phi)}{\tau_{c o m b, N}} \frac{-0.9 \phi_{d}+1.9}{-0.9 \phi+1.9}+0.1
\end{aligned}
$$

これによって，運転中の然料に対して，リアルタイム に当量比を推定, 燃焼期間を計測し，式（14）に代 入することにより，図示熱効率を評価関数として，目 標当量比を決定することができる．なお，当量比の 目標值の設定には，排ガスを考慮する必要があるが， 都市ガスの主成分であるメタンよりもバイオマスガ スの方が同当量比，同じ点火時期であれば THC, NOx ともメタンよりも低くなる (7)こと, バイオマス発電 施設内にエンジンを設置する場合には，排ガスをガス 化炉へ戻すなど，後処理を容易にできること；また， 実用を考えた場合にも，自動制御アルゴリズムが算出 する目標当量比に対して，プログラム上で当量比の上 限值，下限值を設けるなどの措置で排ガスにも容易に 対策が可能となる等の理由により今回は自動制御系 に排ガスの評価関数を組み込んではいない:

\subsection{2 点火時期の目標值決定方法 図 7 に,} 燃焼期間と MBT を与える点火時期の関係を出力毎に

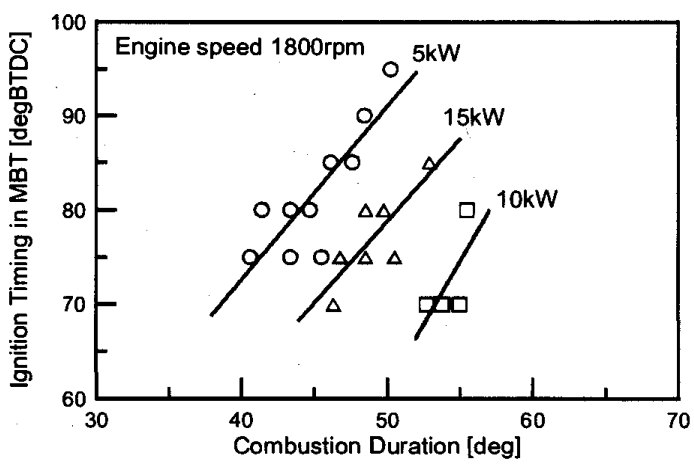

Fig. 7 Relationship between combustion duration and MBT

示す. なお, 図中のデータは, エンジン回転数 $1800 \mathrm{rpm}$ 一定, 燃料は実際のガス化炉で生成されたものを用い, $\mathrm{CH}_{4}$ が 3 4\%, $\mathrm{H}_{2}$ が 12 17\%, CO が 17〜 $21 \%, \mathrm{CO}_{2}$ が 8〜 14\%, $\mathrm{N}_{2}$ が 43〜 49\%の組成範囲で, 当量比は 0.7 〜 1.0 , 負荷 $5 \mathrm{~kW}, 10 \mathrm{~kW}, 15 \mathrm{~kW}$ で取得したものであ る. 負荷が一定の場合, MBT になる点火時期と燃焼 期間の関係はほぼ線形の関係となった．燃料にガソリ ンを想定した火花点火式のエンジンでは， MBT の点 火時期では，条件によらず筒内圧力のピーク值を示す クランクアングルが一定になることが示されており， また，燃焼期間と筒内圧力のピーク值を示すクランク アングルの関係は，燃焼期間が $60 \mathrm{deg}$ 程度までの条件 では線形関係になることが示されている ${ }^{(8)}$.つまり， 燃焼期間がある一定值までの条件であれば，MBTを 与える点火時期は燃焼期間と線形関係になるといえ, 本研究のデータも一般性の高いデータとして取り扱 うことができるものと考えられる.

ここで, この燃焼期間と MBT の点火時期の関係か ら得られる近似直線の切片と傾きを, 図示出力の関数 として整理すると, 式（1 5) の関係式が得られた.

$$
\theta_{i g n, M B T}=\left(-0.403 \frac{W_{c, i}}{W_{c, i, N}}+2.50\right) \tau_{c o m b}-2.57 \frac{W_{c, i}}{W_{c . i, N}}-11.7
$$

よって, 点火時期 $\theta_{i g n, M B T}$ は, 圧力履歴より 1 サイク ル毎に燃焼期間およひ図示熱効率を導出し，それぞれ 導出した值を式（15）に代入することにより決定さ れる.ただし， $W_{c, i, N}$ は出力の值を無次元化するため に用いた図示出力 で, 100[J/cycle]とした. また，点火 時期の目標值を 1 サイクル毎に 1 気筒のみの圧力情 報を用いて導出することから，便宜上，出力の単位は 通常とは異なっている.

ガソリンエンジン等では，一般にノッキングが生じ るまで点火時期を進角させる制御を行う。しかし，本 システムでは, コストの低減を一つの目標としており， 市販エンジンの圧縮比やバルブタイミングの変更は 


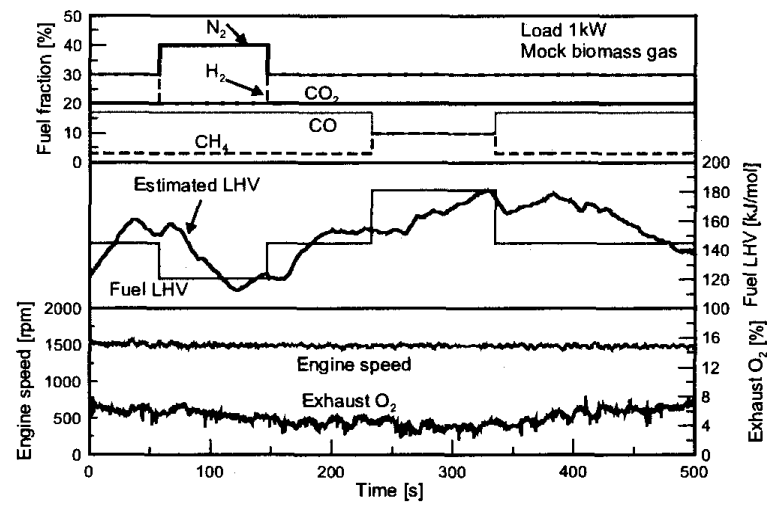

Fig. 8 LHV estimation test

行わないため，進角させてもノッキングが生じないこ ともある，そのため，ガソリンエンジンと同様の点火 時期制御では，進角しすぎて図示熱効率が低下するこ とも起こりえる. 当量比制御用に筒内圧力を計測して いることから，その情報を基に等容度が最大となるよ うに制御を行った方が適当と考えたため，燃焼期間か ら点火時期を決定する方法とした.

\section{4. 高効率運転制御システムによる運転実験}

構築した運転制御システムによる運転試験を行っ た. まず，構築した運転制御システムの制御アルゴリ ズムの動作確認試験を行い, その後発電試験を行った.

\section{$4 \cdot 1$ 制御システムの動作確認}

4-1・1 低位発熱量の推定 構築した制御シス テムが運転中に燃料の低位発熱量を推測できるかを 確認した. 図 8 にはマスフローコントローラーによっ て供給される模擬バイオマスガスを用い, 負荷 $1 \mathrm{~kW}$ 定，目標回転数 $1500 \mathrm{rpm}$ 一定で運転した結果を示す. なお，この実験では，高効率運転条件の予測による当 量比，点火時期の目標值の決定は行わず，外部から強 制的に目標当量比 0.75 一定, 目標点火時期 $-75 \mathrm{deg}$ ATDC 一定を与えた。 $\mathrm{t}=0$ での然料組成は, $\mathrm{CH}_{4}: \mathrm{H}_{2}: \mathrm{CO}: \mathrm{CO}_{2}: \mathrm{N}_{2}=3: 30: 17: 20: 30$ とし, $\mathrm{t}=50$ 付近で, マスフローコントローラーの供給然料組成の指示值 を $\mathrm{CH}_{4}: \mathrm{H}_{2}: \mathrm{CO}: \mathrm{CO}_{2}: \mathrm{N}_{2}=3: 20: 17: 20: 40$ 一と変更し, $\mathrm{t}=$ 150 頃に再び初めの燃料組成へと戻した. さらに, $\mathrm{t}=$ 230 付近では，燃料組成の指示值を $\mathrm{CH}_{4}: \mathrm{H}_{2}: \mathrm{CO}_{2}: \mathrm{CO}_{2}: \mathrm{N}_{2}$ $=10: 30: 10: 20: 30$ 一と変更し, 再び $\mathrm{t}=330$ 付近で然料組 成を元に启した. マスフローコントローラーの燃料流 量指示値の変化に伴い，構築した制御系により計算さ れた低位発熱量も変化した。 またこのように燃料の 組成が変化しても，エンジン回転数は目標值の $1500 \mathrm{rpm}$-定に保つことができていることがわかる. なお，燃料流量指示值より計算した低位発熱量の変化

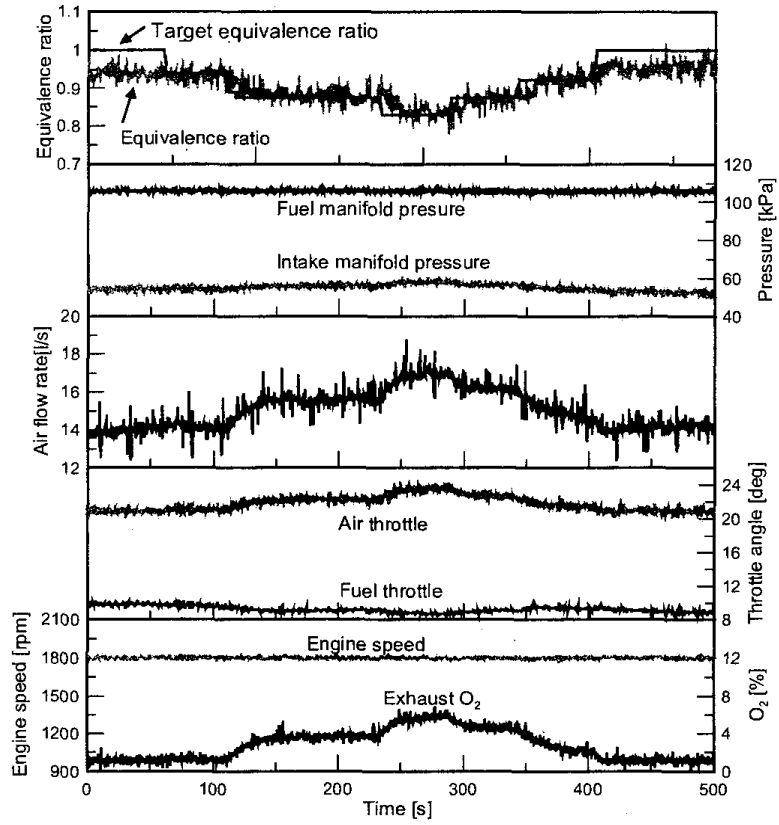

Fig. 9 Operation test with equivalence ratio control

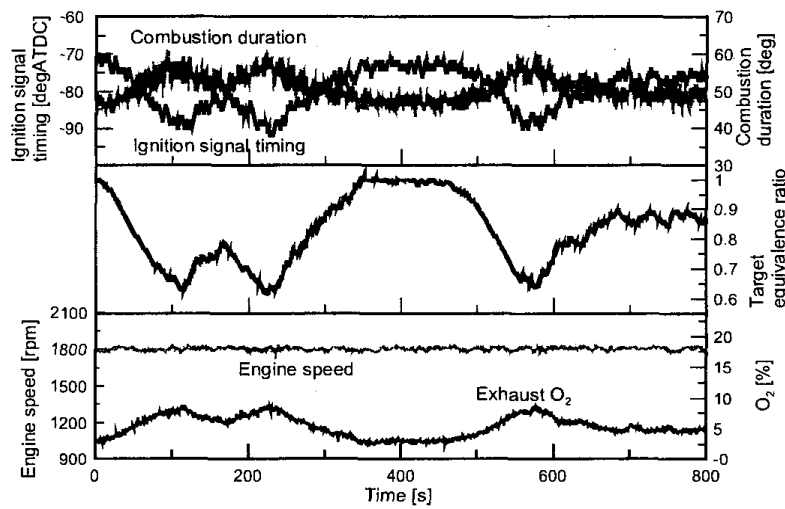

Fig. 10 Operation test with ignition timing control

に比べ，制御系計算值の位相が遅れたのは，燃料供給 配管系に設置されたマスフローコントローラーがエ ンジンから $15 \mathrm{~m}$ ほど上流にあるためである.

4.1・2 当量比制御 図9は，実バイオマスガ スを用い, 目標回転数 $1800 \mathrm{rpm}$, 出力 $10 \mathrm{~kW} \cdots$..定で, 当量比の目標值を手動で変化させた時の結果である. なお，点火時期は，燃焼期間から MBT を計算し自動 制御を行っている. 目標当量比を変化させると運転時 の当量比は追従した. 当量比制御には空気用スロット ルが対态し, 目標当量比が小さくなるにつれ, 空気用 スロットル開度が増加し, 空気流量が増加, 排気 $\mathrm{O}_{2}$ 濃度が高くなっており，制御系が正常に動作している ことが分かる.また, エンジン回転数は目標の $1800 \mathrm{rpm}$ で安定しており，回転数を安定に保ちながら，目標当 量比を変化させて運転できることが確認された。

4・1・3 点火時期制御 実バイオマスガスで, 目標回転数 $1800 \mathrm{rpm}$, 出力 $10 \mathrm{~kW} \cdots$ 定で, 目標当量比 


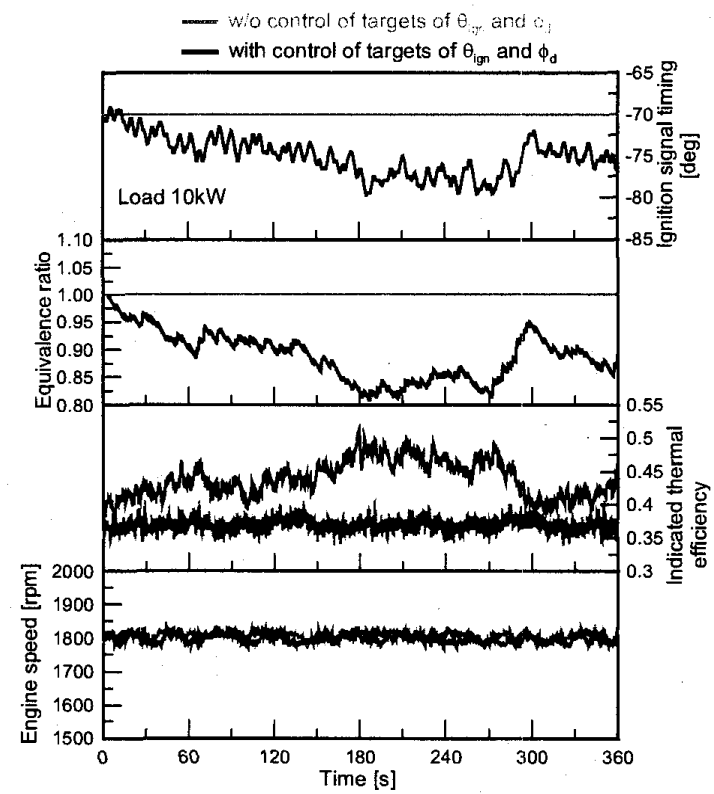

Fig. 11 Effect of control of targets of equivalence ratio and ignition timing

の自動制御系による決定は行わず，手動によって変化 させて運転した際の結果を図 10 に示す. 目標当量比 を低下させた場合には燃焼期間は長期化，増加させた 場合には燃焼期間は短期化し，この変化に応じて，点 火時期は，燃焼期間が長期化する場合には進角，短期 化する場合は遅角しており，適切に制御できているこ とが確認された。

\section{4 - 2 発電試検 これまでに構築した高い効率の} 得られる当量比と点火時期の目標值を燃焼状態に応 じて自動的に設定し運転する制御アルゴリズムを導 入したエンジンシステムで，ガス化炉で生成される実 バイオマスガスを用いて負荷 $10 \mathrm{~kW}$ 一定条件で発電試 験を行った，運転結果を図 11 に示す．図中には比較 のために目標当量比を 1.0 一定, 目標点火時期を -70degATDC 一定とした場合の結果も示してある.こ の条件では当量比を希薄側に制御することにより，熱 効率が大きくなると制御系が判断し，当量比は時間の 経過とともに希薄化し, それに伴い点火時期が早期化 した. しかし，図中 $300 \mathrm{~s}$ 付近で一旦濃い目標值を設定 したことが分かる。これは，当量比の目標值設定が式

（1４）によって決まるため, 希薄化しすぎたことに よって生じる失火の影響は基本的には考慮できてい ない. そのため, 失火回数が増えると, 当量比の目標 值を大きくするといった補償アルゴリズムを別に組 み込んでおり，それが動作したことで，目標当量比が 大きくなったものと考えられる. 図示熱効率は, 当量 比および点火時期を 1.0, -70degATDC と与えた場合よ りも自動制御系に判断させた方が向上しており，構築 したアルゴリズムの有効性が確認された.

\section{5. 結 論}

多様な組成の燃料で，安定にかつ高効率に運転でき る小型ガスエンジンシステムの構築を行った.

当量比変化に対する燃焼期間変化の割合は，燃料に よらず 1 次線形な関係を有しており，当量比と燃焼期 間より，図示熱効率を求めることができること，また， 出力一定時の燃焼期間と MBT の関係も 1 次線形であ ることを明らかにした。これに基づき，筒内圧力情報 から当量比および然焼期間をリアルタイムに推定す ることで高効率運転が可能な当量比および点火時期 の目標値を自動的に決定するアルゴリズムを構築す ることができた.

このアルゴリズムを自動車用エンジンを転用した エンジンシステムに実装し，実バイオマスガスを然料 として実験を行った結果，高効率な運転条件を自動で 判断できていることが確認でき，構築した運転制御ア ルゴリズムの有効性が示された.

\section{参 考 文 献}

(1) Kudo, S., Matsumura S., Kono M. and Hukuda T., "Gas Engine Co-generation by using Pyrolysis Gas Fuel", Clean Energy, Vol.12, No.9, (2003), pp.32-36, (in Japanese)

(2) Goto S., Nishi H., Nakayama S. and Takahashi S., "Development of High Density Gas Engine 22AG", Technical Review of Ishikawajima-harima Heavy Industry, Vol.43, No.6, (2003), pp.216-219, (in Japanese)

(3) Yamasaki Y., Tomatsu G., Nagata Y. and Kaneko S., " Combustion Characteristics of Low-Calorific-Value Gaseous Fuels in Small Gas Engine", Journal of Environment and Engineering, Vol. 4, No.1, (2009), pp.188-197

(4) Yamasaki Y., Tomatsu G., Nagata Y. and Kaneko S., "Operation Control of a Biomass Gas Engine with Real-Time Analysis of In-Cylinder Gas Pressure", Journal of System Design and Dynamics, Vol.2, No. 6, (2008), pp.1284-1295

(5) Sasauchi K., "Outline of Small-scale Gasification and Power Generation System for Woody Biomass ", 10th Kansai heat transfer seminar, (2007), pp 197-200

(6) John B. Heywood, Internal combustion engine fundamentals, McGraw-Hill, (1988)

(7) Yamasaki Y. and Kaneko S., "Study on Small Size Gas Engine with Biomass Gas", Journal of the Combustion Society of Japan, Vol.49, No.150, (2007), pp.16-25,

(8) Fujii I., Kawai M., Ishii K. and Kono M., "MBT Feedback Control System in Spark Ignition Engines -2nd Report Thermodynamic Model Study for MBT and Crank Angle of Maximum Combustion-", Trans. of Society of Automotive Engineers of Japan Vol.28, No.3, (1997), pp.23-28, (in Japanese) 